\title{
What are the factors that contribute to aggression in patients with co-occurring antisocial personality disorder and substance abuse?
}

\author{
BÜLENT DeVrim AKÇAY ${ }^{1}$ \\ https://orcid.org/0000-0002-6308-9327 \\ DuYGu AKÇAY² \\ https://orcid.org/0000-0001-9030-6879 \\ 'Department of Mental Health and Diseases, Gülhane Education and Research Hospital, Ankara, Turkey. \\ ${ }^{2}$ Department of Military Health Services, Ministry of National Defense, Ankara, Turkey.
}

Received: 05/12/2018 - Accepted: 04/15/2020

DOI: 10.1590/0101-60830000000240

\begin{abstract}
Background: A significant number of individuals with high levels of aggression have substance use disorder problems. Objective: This study aimed to evaluate the effect of substance use disorder on aggression in young men with Antisocial personality disorder (ASPD). Methods: This cross-sectional study included 328 patients and were diagnosed with ASPD with a comorbidity of substance use disorder, along with 111 healthy young male subjects. Results: The total aggression scores of the patients with a diagnosis of ASPD were significantly higher than those of the healthy group $(\mathrm{p}<0.001)$. Mean scores of aggression subscale, except for indirect aggression, were higher in patients diagnosed with ASPD $(\mathrm{p}<0.05)$. There was a positive correlation between aggression scores and total API scores in patients diagnosed with ASPD $(\mathrm{p}<0.001)$. Aggression scores were higher when subjects were using volatile substances compared to other substances $(\mathrm{p}<0.05)$. Aggression scores increased with duration of substance use disorder $(\mathrm{p}<0.001)$. Discussion: Substance use disorder should be treated first to mitigate aggression in individuals with ASPD. Patients with severe addiction to volatile substances should be given treatment priority. Further studies are necessary to determine the cause of aggression in individuals who abuse substances.
\end{abstract}

Akçay BD, Akçay D. / Arch Clin Psychiatry. 2020;47(4):95-100

Keywords: Antisocial personality disorder, substance use disorder, aggression, young men.

\section{Introduction}

Aggression, or behavior intended to cause harm, is a common symptom of many psychiatric and personality disorders, particularly antisocial personality disorder (ASPD) - a condition that is significantly hard to treat due to patient- and provider-related difficulties ${ }^{1}$. Studies have shown that ASPD is frequently associated with violent behavior and abuse of alcohol and other substances $2-4$. The use of addictive substances is a global public health problem that leads to increased morbidity and mortality for the user, serious problems in the society and economic burden 5 . In 2015, the World Health Organization reported that approximately $5 \%$ of the global adult population had used a substance at least once and $0.6 \%$ suffered from substance use disorders 6 . Despite the adoption of various measures for prevention in developed countries, which have a higher frequency of substance abuse 6, studies show that relapses are frequent and adherence to treatment is poor ${ }^{7}$. According to the European Drug Report ${ }^{8}$, it is estimated that cannabis, the most commonly used substance, is used by $13.9 \%$ of young adults aged 15-34. In young adults, substance use disorder can lead to changes in attitude and may provoke new behavior including violence, lying, stealing, damaging property, refusing to comply with rules in the school, home or society; they are also known to have a tendency for aggression, demonstrate confrontational behavior against authority figures and look for excuses to fight ${ }^{9-11}$. Considering these effects and the fact that persons with ASPD are at higher risk for substance abuse, the evaluation of the relationships between ASPD, substance abuse and aggression may increase our understanding of the conditions and may prove useful for the determination of risk factors.

As problems such as violent behavior and substance use disorder are more common among young adults and men, this study was planned with an aim to evaluate the effect of substance use disorder on aggression in young males with ASPD.

\section{Methods}

This cross-sectional study was conducted from April 13, 2015 to June 30, 2016 in the psychiatry outpatient clinic of Konya Military Hospital. The study population consisted of ASPD patients with a comorbidity of substance use disorder $(n=567)$ and healthy young male volunteers $(n=210)$. Among these, those who met inclusion criteria were included in the study. A final total of 328 ASPD patients with substance use disorder and 111 healthy young men were included in the study.

The inclusion criteria for the patient group was as follows:

- Being clinically diagnosed with ASPD according to DSMIV-TR diagnostic criteria, and having substance use disorder determined by the Turkish version ${ }^{12}$ of the SCID-II ${ }^{13}$ according to DSM-V diagnostic criteria 5.

- Not having any psychiatric symptoms or any other general condition that causes an Axis-I disorder which is associated with aggression (mental retardation, schizophrenia, schizoaffective disorder, bipolar disorder, major depression, post-traumatic stress disorder, intermittent explosive disorder, and organic psychiatric disorder) according to the Turkish version ${ }^{14}$ of SCID-I15.

- Being literate and voluntarily choosing to participate in the study.

- Not having an active psychotic symptom and not being under the influence of a substance.

- Not meeting diagnostic criteria for mood disorder and not having mental disorders due to psychiatric or organic causes that could cause impulsivity/behavior disorder (other than ASPD).

- Not being under the ongoing influence of a traumatic situation before the interview. 
Healthy men that met the following criteria were included in the control group.

- Those without a chronic medical condition.

- Those who had never received neurological or psychiatric treatment.

- Those who voluntarily chose to participate in the study and were literate.

- Those without Axis I disorders according to SCID-I.

The research commenced after obtaining ethical approval from the Local Ethics Committee of Konya Military Hospital (decree number 2015/01/4). Before inclusion into the study, all participants were informed of the purpose of the research and written consent was obtained.

\section{Data collection}

The demographic characteristics and other data of the patients were recorded during interviews. Aggression and substance abuse were evaluated via the Aggression Scale and Addiction Profile Index (API) questionnaires which were explained and applied to patients by 1 of 3 psychiatrists who all followed a standardized procedure. Before the interview began, the patients were asked if they were currently under the influence of a substance and whether they had recently suffered a traumatic event. In the event that an interview did not conform to prior data, or the patient was considered to be under the influence of a substance (through examination of consciousness when necessary), or the patient became unresponsive, the interview was cancelled and scheduled with another psychiatrist at a later date.

SCID-I: A structured clinical interview scale developed by the American Psychiatric Association for DSM-IV Axis-I diagnoses ${ }^{15}$. A Turkish validity and reliability study of SCID-I was performed by Çorapçioglu et al. ${ }^{14}$.

SCID-II: A structured clinical interview scale developed by the American Psychiatric Association for DSM-III-R Axis-II diagnoses ${ }^{13}$. A Turkish validity and reliability study of SCID-II was performed by Sorias et al. ${ }^{16}$

Aggression Scale: The Aggression Scale was developed by Buss and Peryy (1992), updated by Buss and Waren (1992), and adapted to the Turkish language by $\mathrm{Can}^{17}$. The scale consists of 34 items which evaluate five sub-dimensions including physical aggression, verbal aggression, anger, hostility, and indirect aggression. The scale includes a five-point Likert-type rating organized as: $1=$ Extremely uncharacteristic of me, 2 = Somewhat characteristic of me, $3=$ Slightly characteristic of me, $4=$ Completely characteristic of me, 5 = Extremely characteristic of me. The lowest score is 34 and the highest score is 170 . The evaluation of the scores is performed on a factor basis and not all scores obtained from the scale are used. A high score within a subscale indicates that the individual has aggressive behavior related to that factor.

\section{Addiction Profile Index (API)}

The API is a scale developed by Ögel et al. ${ }^{18}$ for the assessment of different dimensions of addiction and to determine addiction severity. It is a self-reported scale consisting of 37 questions and 5 subscales which measure the characteristics of substance use, diagnostic criteria of addiction, the effect of substance use on the person's life, the strength of desire for substance use, and the motivation to discontinue substance use.

\section{Data evaluation}

The SPSS 15.00 program was used for the analysis of all data obtained in the study. Frequency, mean, and standard deviation were used to assess sociodemographic data (age, socio-economic status, marital status and education). The Chi-square test was used to compare categorical data between patients and controls. Pearson's correlation analysis was used to evaluate associations between aggression scale scores and API scores. The Independent Samples t-test was used to compare normally distributed continuous variables among binary groups, while the ANOVA or Tukey tests were used as post-hoc tests to compare three or more groups. The results were evaluated at the $95 \%$ confidence interval with a $5 \%$ significance level.

\section{Results}

The patient and control groups were similar in terms of age, marital status, education, and socioeconomic status $(p>0.05)$ (Table 1$)$. The mean total aggression score $(103.85 \pm 31.59)$ of the patient group was found to be significantly higher than that of the healthy group $(90.85$ $\pm 21.93)(\mathrm{p}<0.001)$. When the subsections of the aggression scale were compared, the patient group was found to have significantly higher scores in all subscales except for indirect aggression (Table 2).

There was a significant positive correlation between the total API scores and the scores of physical aggression, verbal aggression, anger, hostility, and indirect aggression in patients $(\mathrm{r}=.513, \mathrm{r}=.517, \mathrm{r}=$ $.454, \mathrm{r}=.589, \mathrm{r}=.537$, and $\mathrm{r}=.568$, respectively) $(\mathrm{p}<0.001)($ Table 3$)$

Total aggression score showed moderate positive correlations with the scores obtained from 3 of the API subsections (characteristics of substance use, impact of substance use on the person's life, and strength of the desire for substance use $)(r=.683, r=.621$, and $r .691$, respectively) $(\mathrm{p}<0.001)$. Additionally, total aggression scores were correlated positively with diagnostic criteria of addiction score and negatively with motivation to discontinue substance use score $(\mathrm{r}=$ .491 and $\mathrm{r}=-.393$, respectively) (Table 3 ).

When we examined the substances used by the sample group and their respective mean aggression scores, a significant variance was observed. The Games-Howell test (based on homogeneity) was performed to determine which substances caused a difference in aggression scores; significantly higher aggression scores were noted with use of volatile substances compared to other substances ( $\mathrm{p}<$ $0.05)$. Synthetic cannabinoid users had significantly higher aggression scores than cannabis and heroin users $(\mathrm{p}<0.05)$.

Out of the patients diagnosed with ASPD with a comorbidity of substance use disorder, those who used a single substance had a mean aggression score of $69.55 \pm 29.67$, those who used multiple substances had a mean aggression score of $110.47 \pm 27.43$. Furthermore, those who harmed themselves had a mean aggression score of 116.04 \pm 27.00 , while those who did not harm themselves had a mean aggression score of $82.45 \pm 27.46$; however, this difference was not statistically significant $(\mathrm{p}>0.05)$. Mean aggression scores were significantly higher in those with intravenous drug use compared to those who did not use intravenous drugs $(\mathrm{p}<0.001)$, and higher in those with legal problems compared to those without $(\mathrm{p}<0.001)$. Finally, we also found that aggression scores increased with the duration of substance use disorder $(\mathrm{p}<0.001)$ (Table 4).

\section{Discussion}

In the current study, young men with ASPD and a comorbid substance use disorder were found to have significantly higher aggression compared to controls, as measured by the Buss-Perry Aggression Scale. We also found that all subsections of the aggression and API scales showed significant correlations with total API score and total aggression score. Further analyses demonstrated that using synthetic cannabinoids, ecstasy and volatile substances, intravenous use, having a legal problem and duration of substance use were associated with higher aggression scores.

Our findings conform to prior studies in which substance use was associated with aggressive behavior ${ }^{19-23}$. In the current study, the patient group was found to have higher scores in anger, hostility, and physical and verbal aggression, while indirect aggression was similar with controls. In a very similar study to ours, which compared aggression levels in patients with substance use disorder and patients with comorbid ASPD and substance use disorder, it was 
Table 1. Sociodemographic comparison between patients diagnosed with ASPD with a comorbidity of substance use disorder and healthy participants

\begin{tabular}{|c|c|c|c|c|c|}
\hline & \multicolumn{2}{|c|}{ Substance use disorders $(n=328$ ) } & \multicolumn{2}{|c|}{ Healthy group $(n=111)$} & \multirow{2}{*}{$\begin{array}{c}\text { Significance } \\
\mathrm{p}\end{array}$} \\
\hline & $n$ & $\%$ & $n$ & $\%$ & \\
\hline \multicolumn{6}{|l|}{ Age } \\
\hline 20 & 97 & 29.6 & 35 & 31.5 & \multirow[t]{5}{*}{0.627} \\
\hline 21 & 141 & 43.0 & 51 & 45.9 & \\
\hline 22 & 45 & 13.7 & 16 & 14.4 & \\
\hline 23 & 24 & 7.3 & 4 & 3.6 & \\
\hline 24 & 21 & 6.4 & 5 & 4.5 & \\
\hline \multicolumn{6}{|l|}{ Socio-economic status } \\
\hline Low & 107 & 32.6 & 32 & 28.8 & \multirow[t]{3}{*}{0.669} \\
\hline Medium & 188 & 57.3 & 69 & 62.2 & \\
\hline High & 33 & 10.1 & 10 & 9.0 & \\
\hline \multicolumn{6}{|l|}{ Marital status } \\
\hline Married & 78 & 23.8 & 20 & 18.0 & \multirow[t]{3}{*}{0.446} \\
\hline Single & 240 & 73.2 & 87 & 78.4 & \\
\hline Divorced/Separated & 10 & 3.0 & 4 & 3.6 & \\
\hline \multicolumn{6}{|l|}{ Educational status } \\
\hline Primary school graduate & 62 & 18.9 & 18 & 16.2 & \multirow[t]{3}{*}{0.661} \\
\hline Secondary school graduate & 212 & 64.6 & 77 & 69.4 & \\
\hline High school graduate & 54 & 16.5 & 16 & 14.4 & \\
\hline
\end{tabular}

${ }^{*}$ Chi-square test.

Table 2. Aggression status comparison between patients diagnosed with ASPD with a comorbidity of substance use disorder and healthy participants

\begin{tabular}{|c|c|c|c|c|}
\hline \multirow[t]{2}{*}{ Buss-Perry Aggression Scale } & \multirow{2}{*}{$\begin{array}{c}\text { Substance use disorders }(\mathrm{n}= \\
328) \\
\mathrm{xx} \pm \mathrm{SS}\end{array}$} & \multirow{2}{*}{$\begin{array}{l}\text { Healthy group }(n=111) \\
\qquad x x \pm s s\end{array}$} & \multicolumn{2}{|c|}{ Significance ${ }^{*}$} \\
\hline & & & $\mathrm{F}$ & $p$ \\
\hline Physical aggression & $26.42 \pm 10.73$ & $22.05 \pm 6.37$ & 94.178 & 0.000 \\
\hline Verbal aggression & $15.52 \pm 5.13$ & $14.44 \pm 4.22$ & 10.114 & 0.002 \\
\hline Anger & $24.63 \pm 6.72$ & $21.07 \pm 5.52$ & 7.447 & 0.007 \\
\hline Hostility & $22.45 \pm 6.59$ & $18.04 \pm 5.15$ & 6.160 & 0.013 \\
\hline Indirect aggression & $14.84 \pm 5.30$ & $15.24 \pm 4.82$ & 3.353 & 0.068 \\
\hline Total aggression score & $103.85 \pm 31.59$ & $90.85 \pm 21.93$ & 34.064 & 0.000 \\
\hline
\end{tabular}

${ }^{*}$ T-test in independent groups.

Table 3. Correlation between aggression scores and API scores in patients diagnosed with ASPD with a comorbidity of substance use disorder

\begin{tabular}{|c|c|c|}
\hline \multirow[t]{2}{*}{ Buss-Perry Aggression Scale } & \multicolumn{2}{|c|}{ Total API scores } \\
\hline & $\mathrm{r}$ & $\mathrm{p}^{*}$ \\
\hline Physical aggression & 0.513 & 0.000 \\
\hline Verbal aggression & 0.517 & 0.000 \\
\hline Anger & 0.454 & 0.000 \\
\hline Hostility & 0.589 & 0.000 \\
\hline Indirect aggression & 0.537 & 0.000 \\
\hline \multirow[t]{2}{*}{ Buss-Perry Aggression Scale } & \multicolumn{2}{|c|}{ Total aggression scores } \\
\hline & r & $p^{*}$ \\
\hline Substance use disorder characteristics & 0.683 & 0.000 \\
\hline Diagnosis & 0.491 & 0.000 \\
\hline Impact on life & 0.621 & 0.000 \\
\hline Strong urge & 0.691 & 0.000 \\
\hline Motivation & -0.393 & 0.000 \\
\hline Total API scores & 0.568 & 0.000 \\
\hline
\end{tabular}

* Significant correlation at 0.001 . 
Table 4. Comparison of aggression scores of patients diagnosed with ASPD with a comorbidity of substance use disorder with certain descriptive information

\begin{tabular}{|c|c|c|c|c|}
\hline & \multirow[b]{2}{*}{$n(\%)$} & \multirow{2}{*}{$\begin{array}{c}\text { Total aggression score } \\
\mathrm{xx} \pm \mathrm{SS}\end{array}$} & \multicolumn{2}{|c|}{ Significance* } \\
\hline & & & $\mathrm{F}$ & $\mathrm{p}$ \\
\hline \multicolumn{3}{|l|}{ Most frequently used substance } & \multirow[t]{6}{*}{11.171} & \multirow[t]{6}{*}{$0.000^{* *}$} \\
\hline Cannabis & $158(48.2)$ & $95.80 \pm 32.42$ & & \\
\hline Heroin & $79(24.1)$ & $100.53 \pm 28.89$ & & \\
\hline Synthetic cannabinoid & $56(17.1)$ & $119.64 \pm 28.93$ & & \\
\hline Pill (Ecstasy) & $20(6.1)$ & $115.10 \pm 22.40$ & & \\
\hline Volatile substance (Thinner, Bally) & $15(4.6)$ & $132.20 \pm 8.08$ & & \\
\hline \multicolumn{5}{|l|}{ Substance use disorder characteristics } \\
\hline Single substance use disorder & $53(16.2)$ & $69.55 \pm 29.67$ & 0.483 & $0.487^{*}$ \\
\hline Multiple substance use disorder & $275(83.8)$ & $110.47 \pm 27.43$ & & \\
\hline \multicolumn{5}{|c|}{ Intravenous substance use disorder status } \\
\hline Yes & $41(12.5)$ & $117.44 \pm 23.04$ & \multirow[t]{2}{*}{13.145} & \multirow[t]{2}{*}{$0.000^{*}$} \\
\hline No & $287(87.5)$ & $101.91 \pm 32.19$ & & \\
\hline \multicolumn{5}{|l|}{ Legal problem status } \\
\hline Yes & $161(49.1)$ & $111.92 \pm 27.53$ & \multirow[t]{2}{*}{17.277} & \multirow[t]{2}{*}{$0.000^{*}$} \\
\hline No & $167(50.9)$ & $96.08 \pm 33.33$ & & \\
\hline \multicolumn{5}{|l|}{ Self-harm } \\
\hline Yes & $209(63.7)$ & $116.04 \pm 27.00$ & \multirow[t]{2}{*}{0.470} & \multirow[t]{2}{*}{$0.494^{*}$} \\
\hline No & $119(36.3)$ & $82.45 \pm 27.46$ & & \\
\hline \multicolumn{5}{|l|}{ Duration of substance use disorder } \\
\hline $0-1$ year & $38(11.6)$ & $81.03 \pm 33.35$ & \multirow[t]{3}{*}{24.259} & \multirow[t]{3}{*}{$0.000^{* *}$} \\
\hline $2-5$ year & $199(60.7)$ & $101.23 \pm 30.96$ & & \\
\hline $6-12$ year & $91(27.7)$ & $119.12 \pm 24.81$ & & \\
\hline
\end{tabular}

* T-test in independent groups. ** Analysis of variance.

found that patients with the comorbid condition were significantly more aggressive than those with only substance abuse ${ }^{24}$. This finding is supported by the fact that both conditions elevate impulsivity and decrease inhibitory control ${ }^{25,26}$, suggesting that ASPD and substance abuse both contribute to the aggression of patients. A study by Sökmen et al., which was performed on adolescents with substance addiction, reported that physical aggression and hostility scores were higher among adolescents with addiction, while verbal aggression, anger, and indirect aggression scores were surprisingly lower, revealing a contrast to our study ${ }^{11}$. However, all of our patients had comorbid ASPD and substance abuse, therefore the aggressive characteristics of our patients would be expected to be higher than those without ASPD. Furthermore, Hyde et al. reported that antisocial behavior during the adolescence was associated with a higher risk of ASPD diagnosis in adulthood ${ }^{27}$, which may show that earlier substance abuse that causes aggression and/or antisocial behavior may transform to ASPD later on in life, further increasing aggression. In agreement with this hypothesis, comorbid ASPD and substance abuse has been reported to be associated with predisposition to aggressive behavior ${ }^{28,29}$. The key point in this association may be the fact that ASPD patients and those with substance abuse have similar characteristics in terms of seeking stimulus, suggesting a bidirectional relationship between the conditions and therefore leading to the age old question "which comes first?". Although the literature is limited in this aspect, it may be reasonable to suggest that the search for stimulus may be the initial reason that adolescents succumb to drug use, leading to antisocial/violent behavior and finally forming a vicious cycle embodied by ASPD. However, this train of thought is in no way the only explanation of the relationship between the conditions and requires confirmation. Therefore, we believe that treating stimulus seeking behavior before starting direct therapy for substance abuse may increase the likelihood of positive clinical outcome. Although the overwhelming majority of studies in this field demonstrate that ASPD and substance abuse both contribute to aggression, contrasting findings also exist. For instance, a study by Shorey et al. showed that aggressive behavior was not associated with alcohol or substance abuse in patients with ASPD ${ }^{30}$.
The fact that indirect aggression was not significantly increased in the patient group may be associated with the features of indirect aggression itself. Indirect aggression requires more advanced cognitive skills compared to other forms of aggression ${ }^{31,32}$. The similarity between indirect aggression behavior score of the groups may be attributed to the fact that the majority of the study group was comprised of males with low education levels, while the impairment of social-cognitive abilities among those with substance use disorders may also be another explanation to the lack of difference.

Ekinci et al..$^{33}$ found that the scores obtained in subsections of the API, such as the effect of substance use on the person's life, the desire for substance use, and the motivation to discontinue substance use, were higher among those with higher aggression scores. The same study stated that, with increased anger levels, the impact of substance use disorder on the person's life increases, along with the desire to use the substance. However, Kaplan et al. reported no statistically significant relationship between aggression level and API, among children living in the streets ${ }^{34}$. Contrastingly, the current study found that aggression scores were significantly correlated with API. When examining the correlations between total aggression scores and the API subscales, it can be seen that motivation to discontinue substance use decreases as aggression scores increase. It is assumed that the level of aggression increases when motivation to discontinue substance use decreases, caused by the inability to decide to make a change or not, a situation with which they cannot cope. Therefore, close follow-up and supportive conduct during treatment may be beneficial for patients with high motivation to discontinue drug use.

In the current study, the type of substance was found to be a significant contributor to aggression scores. Those who used synthetic cannabinoids, ecstasy and volatile substances were found to have higher mean total aggression scores. A large meta-analysis study reported cocaine was the substance with the strongest link to psychological, physical, and sexual aggression. Cannabis was also associated with aggression towards a partner ${ }^{35}$. Other studies also reported higher aggression scores among those who used volatile substances ${ }^{36}$. Although earlier studies have associated cannabis with 
increased aggression ${ }^{37}$, our findings show that the control group and cannabis users had comparable total aggression scores $(90.85 \pm 6.37$ vs. $95.80 \pm 32.42$ ). However, the variance in scores among those using cannabis demonstrate that the effects of cannabis cannot be considered uniform among all users.

Similar to the study by Kaplan, the aggression level of patients were found to increase with longer duration of substance use in our study group, and the aggression scores of those who had legal problems were significantly higher than those who had no legal problems ${ }^{34}$. As these substances weaken inhibitory control mechanisms and lead to higher activity, individuals are prone to exerting more aggressive and uncontrolled behaviors ${ }^{20}$. Substance use disorder encourages individuals to disobey rules and exert destructive behaviors such as harming themselves and the environment, increasing their tendency to commit crimes.

Violent acts and aggressive behavior in patients with substance abuse may also be associated to the fact that users commit crimes to acquire money for access to the substance ${ }^{20}$. This possibility is an important contributor to the high level of aggression among the young men that participated in this study. One of the study limitations is that the majority of patients were soldiers who were aged between 20-25 years; therefore, the findings can be generalized only for young males aged 20 to 25 years of age. Similar studies with larger sample sizes are needed to obtained more conclusive results. Our findings suggest that substance use disorder is mediated by aggression. Therefore, aggression is an important factor that should be evaluated in the treatment of substance addiction. Particularly in the intervention studies to be conducted, those with high addiction severity and patients who use volatile substances should be considered as the priority treatment group. Further studies are necessary to determine the causes of aggression in substance use disorders and to evaluate the relationships between ASPD and substance abuse.

\section{Disclosure}

The authors report no conflicts of interest.

\section{Research support}

This study wasn't received funded.

\section{References}

1. Glenn AL, Johnson AK, Raine A. Antisocial personality disorder: a current review. Current psychiatry reports. 2013;15(12):427.

2. Žarković Palijan T, Radeljak S, Kovač M, Kovačević D. Relationship Between Comorbidity and Violence Risk Assesment in Forensic Psychiatry-The Implicaton of Neuroimaging Studies. Psychiatria Danubina. 2010;22(2):253-6

3. Fountoulakis KN, Leucht S, Kaprinis GS. Personality disorders and violence. Current opinion in psychiatry. 2008;21(1):84-92.

4. Zimmerman M, Rothschild L, Chelminski I. The prevalence of DSM-IV personality disorders in psychiatric outpatients. Am J Psychiatry. 2005 Oct;162(10):1911-8.

5. Turhan E, İnandi T, Özer C, Akoğlu S. Üniversite öğrencilerinde madde kullanimi, şiddet ve bazi psikolojik özellikler. Turk J Public Health. 2011;9(1):33-44.

6. Merz F. United Nations Office on Drugs and Crime: World Drug Report 2017. SIRIUS-Zeitschrift für Strategische Analysen. 2017;2(1):85-86.

7. Raes V, De Jong CA, De Bacquer D, Broekaert E, De Maeseneer J. The effect of using assessment instruments on substance-abuse outpatients' adherence to treatment: a multi-centre randomised controlled trial. BMC Health Serv Res. 2011;11:123.

8. Team Ee. The European Monitoring Centre for Drugs and Drug Addiction publishes the European Drug Report 2013: trends and developments. Euro surveillance: bulletin Europeen sur les maladies transmissibles. European communicable disease bulletin. 2013;18(22).

9. Simmons S, Suarez L. Substance Abuse and Trauma. Child and adolescent psychiatric clinics of North America. 2016;25(4):723-34.
10. Brady KT, Myrick H, McElroy S. The relationship between substance use disorders, impulse control disorders, and pathological aggression. Am J Addict. 1998;7(3):221-30.

11. Çataloğlu B. Madde kullanan ve kullanmayan ergenlerin psikolojik sağlamlık ve aile işlevleri açisindan karşilaştirilmasi, DEÜ Eğitim Bilimleri Enstitüsü; 2011.

12. Coskunol H, Bagdiken I, Sorias S, Saygili R. The reliability and validity of the SCID-II Turkish Version. Turk Psikoloji Dergisi. 1994;9(32):26-9.

13. First MB, Spitzer RL, Gibbon M, et al. The structured clinical interview for DSM-III-R personality disorders (SCID-II). Part II: Multisite test-retest reliability study. J Pers Disord. 1995;9(2):92-104.

14. Çorapçioğlu A, Aydemir Ö, Yildiz M, Esen A, Köroğlu E. DSM-IV Eksen I Bozuklukları (SCID-I) için yapilandirilmiş klinik görüşme, klinik versiyon. Ankara: Hekimler yayin birliği. 1999.

15. Data D. Structured clinical interview for DSM-IV axis I disorders. Washington: American Psychiatric Press; 1997.

16. Sorias S, Saygili R, Elbi H, Vahip S, Mete L, Nifirne Z. Structured clinical interview for DSM-III-R personality disorders, Turkish version. Izmir: Ege Universitesi Basimevi. 1990.

17. Can S. Aggression Questionnaire adli ölçegin Türk popülasyonunda geçerlik ve güvenirlik çalismasi. Yayimlanmamis uzmanlik tezi, Gülhane Askeri Tip Akademisi, Ruh Sagligi ve Hastaliklari Servisi Sefligi, Istanbul. 2002.

18. Ögel K, Evren C, Karadağ F, Gürol T. Bağimlilik Profil İndeksi'nin (BAPI) geliştirilmesi, geçerlik ve güvenilirliği. Türk Psikiyatri Dergisi. 2012;23(4):264-73

19. Algül A, Ateş MA, Gülsün M, Doruk A, Semiz ÜB, Başoğlu C, et al. Antisosyal kişilik bozukluğu olgularında kendini yaralama davranişinin saldirganlik, çocukluk çaği travmalari ve dissosiyasyon ile ilişkisi. Anadolu Psikiyatri Dergisi. 2009;10:278-85.

20. Altuner D, Engin N, Gürer C, Akyay I, Akgül AJTAD. Madde kullanımı ve suç ilişkisi: kesitsel bir araştirma. 2009;7(2):87-94.

21. Pinhey TK, Wells NR. Asian-Pacific Islander adolescent methamphetamine use: does ice increase aggression and sexual risks? Subst Use Misuse. 2007;42(11):1801-9.

22. Plüddemann A, Flisher AJ, McKetin R, Parry C, Lombard C. Methamphetamine use, aggressive behavior and other mental health issues among high-school students in Cape Town, South Africa. Drug Alcohol Depend. 2010;109(1-3):14-9.

23. Omura JD, Wood E, Nguyen P, Kerr T, DeBeck K. Incarceration among street-involved youth in a Canadian study: implications for health and policy interventions. Int J Drug Policy. 2014;25(2):291-6.

24. Alcorn JL 3rd, Gowin JL, Green CE, Swann AC, Moeller FG, Lane SD. Aggression, impulsivity, and psychopathic traits in combined antisocial personality disorder and substance use disorder. J Neuropsychiatry Clin Neurosci. 2013;25(3):229-32.

25. Fossati A, Barratt ES, Borroni S, Villa D, Grazioli F, Maffei C. Impulsivity, aggressiveness, and DSM-IV personality disorders. Psychiatry Res. 2007;149(1-3):157-67.

26. Rogers R, Jordan MJ, Harrison KS. Facets of psychopathy, Axis II traits, and behavioral dysregulation among jail detainees. Behav Sci Law. 2007;25(4):471-83.

27. Hyde LW, Burt SA, Shaw DS, Donnellan MB, Forbes EE. Early starting, aggressive, and/or callous-unemotional? Examining the overlap and predictive utility of antisocial behavior subtypes. J Abnorm Psychol. 2015;124(2):329-42.

28. Moeller FG, Dougherty DM. Antisocial personality disorder, alcohol, and aggression. Alcohol Res Health. 2001;25(1):5-11.

29. Moeller FG, Dougherty DM, Rustin T, et al. Antisocial personality disorder and aggression in recently abstinent cocaine dependent subjects. Drug Alcohol Depend. 1997;44(2-3):175-82.

30. Shorey RC, Elmquist J, Anderson S, Stuart GL. The Relationship between Antisocial and Borderline Features and Aggression in Young Adult Men in Treatment for Substance Use Disorders. J Psychoactive Drugs. 2016;48(2):115-23

31. Moroschan G, Hurd PL, Nicoladis E. Sex differences in the use of indirect aggression in adult Canadians. Evolutionary Psychology. 2009;7(2):147470490900700201.

32. Öcel HJJoFoLEFD. Üniversite Öğrencilerinde Dolayli Saldirganliğin Kullaniminda Cinsiyet Farkliliklari. 2011;28(2). 
33. Ekinci S, Yalçınay M, Uğur Kural H, Kandemir H. Madde Bağımliliği Olan Hastalarin Ebeveynlerinde Öfke Düzeyi: Öfkenin, Depresyon ve Anksiyete Düzeyi ile İlişkisi. Klinik Psikiyatri Dergisi. 2016;19(3):125-9.

34. V. K. Sokakta yasayan madde bağimlisi çocuklarda öfke ve saldirganlik düzeyi 2015.

35. Moore TM, Stuart GL, Meehan JC, Rhatigan DL, Hellmuth JC, Keen SM. Drug abuse and aggression between intimate partners: a meta-analytic review. Clin Psychol Rev. 2008;28(2):247-74.
36. Williams JF, Storck M. Inhalant abuse. Pediatrics. 2007;119(5):1009-17.

37. Smith PH, Homish GG, Leonard KE, Collins RL. Marijuana withdrawal and aggression among a representative sample of U.S. marijuana users. Drug Alcohol Depend. 2013;132(1-2):63-8. 